\title{
A MODEL FOR \\ JUSTICE DELIVERY? \\ The Specialised Commercial Crime Court
}

Antony Altbeker, freelance researcher

ipcf@iafrica.com

The Specialised Commercial Crime Court was established to hear cases of commercial criminality, brought to trial by the Specialised Commercial Crime Unit. The integration of the three main functions of the criminal justice system - investigation, prosecution and adjudication - is highly regarded as one of the best examples of succesful criminal justice reform in South Africa. But before this particular model is replicated elsewhere, its undoubted success must be interrogated. However, it is difficult to be sure just what it is that has generated the service delivery improvements.

$\mathrm{T}$ he Specialised Commercial Crime Court opened its doors in November 1999, a few months after the establishment of the similarly named Specialised Commercial Crime Unit (SCCU). The unit consists of a team of prosecutors led by a deputy director of public prosecutions, and is tasked with bringing cases of commercial criminality to trial. The court consists of a pair of regional courts, presided over by two severe and distinguished magistrates. The SCCU and, therefore, the court, handles all the cases dealt with by the Pretoria-based Commercial Branch of the SAPS Detective Service. Thus the investigators, prosecutors and magistrates form a virtually seamless criminal justice process, entirely dedicated to dealing with cases falling within the mandate of the Commercial Branch in the jurisdiction of the Pretoria Regional Court.

The existence of this court, and, more importantly, the integration of the three main functions of the criminal justice system - investigation, prosecution and adjudication - is regarded by many as one of the best examples of successful criminal justice reform implemented in the past few years. Recent research into the functioning of the court has confirmed that this belief is fully warranted. However, the research suggests that its success can partly be explained by factors that may not be replicable elsewhere. In addition, the research suggests that it is impossible to quantify the extent to which this court is more effective and more efficient than other courts, given the inadequacy of the available data and the fact that its case profile differs dramatically from those of other courts.

But before looking at the reasons for the success of the court, it is worth looking at the logic of court specialisation and what it might be expected to achieve.

\section{D oes the specialisation of criminal justice institutions enhance service delivery?}

The basic rationale for the existence of the Specialised Commercial Crime Court is the perceived need to harness scarce criminal justice expertise in the field of commercial crime, and to integrate investigative and prosecutorial functions. In the case of other specialised courts, the motivation for their creation has hinged more on 
the implementation of transformative social policies. Both the Land Claims Court and the Labour Court, for instance, were created by legislation and enjoy equal status with other high courts. However, the establishment of these two courts was primarily driven by the need to ensure that the legal system would have the institutional capacity to implement the policy objectives underpinning the passage of those particular pieces of legislation.

In these cases, which one might call 'court specialisation' proper, a court is established to hear a predetermined and narrow set of cases arising from the very legislation that created the court in the first place. The specialised courts are therefore part of the machinery of policy implementation. Various arguments are made to validate their existence, most of which boil down to the need to recognise that the existing institutions of the law are, for whatever reason, either unwilling or unable to give effect to the relevant policy with sufficient consistency, determination or speed.

The primary rationale for creating these institutions is, therefore, to ensure that a particular area of the law is able to develop rapidly and consistently, and to ensure that redress for matters brought to trial in terms of these pieces of legislation is achieved as quickly as possible. In these particular cases the laws relate to important components of the transformation of South Africa's economy and society, and parliament places a portion of the law under the exclusive jurisdiction of these courts. The Specialised Commercial Crime Court, on the other hand, was established in order to harness scarce investigative and prosecutorial resources in pursuing commercial criminals, and to manage them in ways that enhance the quality of the cases brought to court. The court has to ensure that justice is done more speedily than might be the case in courts with more open rolls.

There are, therefore, aspects of the motivation for the establishment of a Specialised Commercial Crime Court that resemble the arguments for the creation of the other statutory specialised courts. There are, however, also important differences; namely, where this court is located in the South
African court structure, the way in which the jurisdiction of the court is defined, and how its decisions relate to the development of the law elsewhere in the legal system.

Thus, although the Specialised Commercial Crime Court hears only cases of commercial crime, it does so as an ordinary regional court, bound by the same rules of precedence binding other courts. Moreover, if cases are heard elsewhere, no laws are violated and no person's rights or interests are harmed. In addition, personnel in this court are treated identically to all other personnel in the normal court structure - unlike the personnel in the statutory specialised courts.

Given these differences in structure, it seems that the specialisation of courts could take two distinct routes. The one option is court specialisation proper, where legislation provides for the creation of courts outside of the normal structure, and sets the jurisdiction of those courts. The second is what might be called 'court dedication', where an ordinary court is reserved for the hearing of a limited range of cases. Given the legal and organisational difficulties with the former approach, it would seem sensible to suggest that in most cases, the latter would be a more practical alternative.

Before endorsing the creation of a wide range of specialised and dedicated courts, however, it should be noted that there are some associated dangers. Chief among these is the risk that, precisely because of the dedicated character of these courts, the people involved in cases before the court will become overly familiar with one another. This has the potential to subvert the cause of justice by undermining the appropriate objectivity and indifference of the officials of court. Indeed, in the worst case scenario, it is possible that corrupt relationships will develop in these environments. These are dangers that need to be guarded against and weighed up against the potential benefits of specialisation or dedication.

\section{The Specialised Commercial Crime Court}

As described above, the Specialised Commercial Crime Court consists of two regional courts dedicated to the hearing of cases brought to it by 
the Commercial Branch and the SCCU of the National Prosecution Authority in Pretoria. As the names of the institutions suggest, these cases are all of 'commercial criminality'. This is a somewhat vague classification that includes a range of different types of fraud, some categories of theft, and a variety of statutory offences arising from around 60 pieces of legislation governing the conduct of business in South Africa. Despite the range of these offences, the core work of these dedicated criminal justice institutions revolves around fraud and theft cases which are too serious to be heard in district courts, but not serious enough to be heard in the high courts. The investigation and prosecution of cases that are believed to involve organised criminality are, however, the responsibility of the Directorate of Special O perations.

According to the staff in these institutions there are a number of advantages in this model:

- investigations, being the joint responsibility of investigators and prosecutors, are generally better managed and more speedily completed;

- prosecutors are better prepared when their cases eventually come to trial;

- all role-players, magistrates included, understand and appreciate the legal and factual issues at stake in these cases because of their heightened expertise and experience.

The statistics that are available suggest that, much like other regional courts, the Specialised Commercial Crime Court will close about nine or ten cases per magistrate per month. While this raw number does not suggest any dramatic increase in efficiency and effectiveness, the fact that nearly $90 \%$ of all cases result in convictions suggests that, in fact, the prosecution and police handle these cases with a high level of competence. Bearing in mind that commercial crimes are on average a good deal more complicated than other forms of criminal offence, this is a notew orthy statistic. How ever, the lack of appropriate data from courts with similar case portfolios makes it impossible to say just how much more effective and efficient this court actually is.

\section{Success factors}

Even though there are inadequate data on this particular model, we do know that there are certain external factors that contribute to its success. Chief among these is, undoubtedly, the fact that, compared to many other regional courts, this court has more resources. It has, for instance, more prosecutors per court than the national average, and, of equal importance, the SCCU has managed to attract and retain high calibre personnel. This, of course, reflects positively on the management of the SCCU. It also highlights an unintended positive effect of specialisation itself: by creating an environment in which staff can specialise in cases in which they have an interest, the SCCU has found that that the turnover of staff has fallen dramatically.

A second factor reflecting the success of the model has been the extraordinary commitment of management staff in both the commercial branch and the SCCU to co-operate with each other. This, sadly, is not always the case in multi-agency initiatives in the criminal justice system. There is no question in the minds of staff that this could have been different, and that a lack of co-operation would have doomed the initiative to failure. How ever, this does not mean that there has been no tension between staff in the different agencies, as that would have been truly miraculous. What has happened, how ever, is that the management staff, assisted by Business Against Crime (BAC), have set up structures and systems to manage those tensions, and have committed themselves to resolving them when they arise.

This involvement of BAC is yet another factor explaining the success of the model. Although most of BAC's role may be described as facilitating or catalytic, it has also assisted in the provision of administrative and operational resources. It has played a particularly important role in securing the services of skilled personnel, many of whom have come out of retirement to assist in the development of staff competencies in the SCCU and Commercial Branch.

Because of these additional factors it is difficult to assess how important the court model is in explaining the success of the initiative and, therefore, the extent to which such successes might be replicated elsewhere. But there is no doubt that it has accomplished a great deal. 


\section{Conclusion}

Given the uncertainties involved in assessing the reasons for the success of the Specialised Commercial Crime Court, it is not possible to offer recommendations for or against the rollout of this model to other jurisdictions or other forms of criminality. However, if the response to the Immigration Bill is anything to go by, it would appear that the department of justice and constitutional development, together with the responsible portfolio committee in parliament, have developed a view that so-called court specialisation is, in general, undesirable. (This being the creation of separate courts with legally defined mandates.) It is submitted that this approach is correct. Whether and when courts should be dedicated to specific matters, remains something of an open question. 